\title{
Currency crisis transmission through international trade ${ }^{\hbar}$
}

\author{
Jamal Ibrahim Haidar \\ The World Bank, United States \\ Paris School of Economics, France \\ University of Paris 1 Panthéon-Sorbonne, France
}

\section{A R T I C L E I N F O}

\section{Article history:}

Accepted 8 September 2011

Submitted 15 June 2010

\section{JEL classification:}

E1

E5

F1

F4

Keywords:

International trade

General equilibrium model

Currency crisis

Contagion

Capital flows

Exchange rate movement

\begin{abstract}
A B S T R A C T
The Eurozone recent crisis has shown how balance of payments problems in less developed European Monetary Union (EMU) member countries can affect EMU trading partners, spreading the crisis to a larger group of countries. This paper introduces a three-country dynamic general equilibrium model to analyze whether and how terms of trade effects can generate a spillover effect or a currency crisis transmission between countries. Specifically, using a two period model, it incorporates world market clearing conditions for tradables into a new theoretic model, analyzes net capital flow movements between countries, and establishes cross-border macroeconomic linkages. This paper shows how a currency crisis can transmit through the real (trade) sector channel of the economy.
\end{abstract}

(C) 2011 Elsevier B.V. All rights reserved.

\section{Introduction}

Currency crises transmission is a recurring phenomenon with substantial empirical and potentially long lasting effects on (groups of countries in) the world economy. This paper presents a theory for analyzing whether inter-country trade can be responsible for the transmission of a currency crisis, which has important implications for understanding the empirical phenomenon in general and possibly also its regional dimensions. Specifically, it tries to (i) show how a currency crisis can transmit through the real (trade) sector channel; (ii) present how changes in a foreign country's capital flow condition can influence home country's exchange rate through the change in terms of trade; (iii) mathematically prove that the significance of the real sector channel between two countries is positively associated

\footnotetext{
is The first draft of this paper was written when Jamal Ibrahim Haidar was a PhD student at University of California, Berkeley. The author would like to thank three anonymous referees for useful comments; Barry Eichengreen, Maurice Obstfeld, and Andrew Rose for helpful discussions; and the UC Berkeley Irma Adelman Fellowship for funding. Ammar Yasser Safa provided inspiration. The findings, interpretations, and conclusions expressed in this paper are entirely those of the author. They do not necessarily represent the views of the International Bank for Reconstruction and Development/ World Bank and its affiliated organizations, or those of the Executive Directors of the World Bank or the governments they represent.

E-mail addresses: JHaidar@worldbank.org, Jamal.Haidar@ParisSchoolofEconomics.Eu, Jamal.Haidar@malix.univ-paris1.fr.
}

with their trade levels; (iv) offer a new trade-related explanation for the occurrence of currency crises between countries; and (v) describe how capital movement between two countries can lead to a currency crisis in one of these countries and in a third country. Key post-2008 developments in international macroeconomics motivate this research paper.

The potential magnitudes and effects of currency crisis are getting more attention from policy makers across countries. The meltdown in Greece caused concerns for Spain and the whole Eurozone, for instance. ${ }^{1}$ Governments and international organizations are backing significant rescue packages across countries - i.e. the 2011 bailout for Greece. $^{2}$ Among the reasoning behind these rescue packages is that, in their absence, other markets can experience serious repercussions. Indeed, a sign of default in a relatively small economy (i.e. compared to US or European Union) can push other markets into trouble, a run on the Euro, and questioning about the competence of the Eurozone establishment.

Why should economic policy makers have a closer look at currency crisis in neighboring countries? First, by following up recent developments in Eurozone, an alert observer can notice that if a heavilyindebted economy defaults, currency crisis may take place in global markets and not be limited to the Eurozone. For instance, France holds $33 \%$ of

\footnotetext{
1 Haidar (2011a) provides more details.

2 See Haidar (2009a) for more details on the US case.
} 
Greece's debt, 20\% of Spain's debt, and 17\% of Portugal's debt. And, Germany is not in a much different position. Thus, a default in any of these heavily-indebted economies presents a threat to banks in the Eurozone and questions their survival potential. ${ }^{3}$ Second, a depreciation in the value of the Euro has implications on other markets given the Eurozone represents $7 \%$ of global consumption and $20 \%$ of international trade. In case the Euro does not recover, European markets would import less as domestic goods would be relatively cheaper, causing a competition challenge to exporters in other markets (mainly in United States and China).

Comparatively, Russia was in Greece's current position 14 years ago. Ruble strived to rebound, and Russia sought monetary support from the IMF. Back then, Russia pegged the Ruble to the US dollar, as Greece is currently locked to the Euro. During the same period, demand on Russia's oil decreased because of the 1997 Asian economic contraction, causing Russian oil export prices to diminish as well and the Ruble to depreciate. However, Russia kept the currency peg in place as the US dollar was appreciating and investors found in it a safe harbor. ${ }^{4}$ The gap between low productivity and high wages in Greece today is similar to Russia's oil woes back then. Similary, a significant currency depreciation in Thailand, which preceded a severe trade outflow from Thailand, was a key reason behind the 1997 Asian currency crisis, which reached to neighboring Korea and Indonesia. ${ }^{5}$ These facts trigger questions related to whether trade relationship can transmit currency crisis.

Literature on the circumstances that make currency crisis transmit contagiously across countries is present although it is relatively little. For instance, Neary (1988) attempted to provide a simple, compact derivation of the determinants of the real exchange rate in a multicommodity framework to show the importance of the equilibrium real exchange rate and the relative price of non-traded to traded goods consistent with balance-of-payments equilibrium. Moreover, Willman (1988) and Goldberg (1994) endogenized relative prices, allowing events abroad to influence the real exchange rate and domestic competitiveness. Flood and Garber (1984) and Claessens (1991) introduced uncertainty about the domestic policy process. Flood and Garber, followed by Obstfeld (1986), added the idea of a contingent policy process, in which one-time events could lead the authorities to substitute one policy for another, thereby introducing the possibility of self-fulfilling speculative attacks.

Gerlach and Frank (1995)'s study was among the first studies that addressed our question of interest. The paper considered two economies (Finland and Sweden) with trade and financial linkages, especially when the value of Swedish Krona depreciated after the fall of the Finnish Markka in 1992. In their model, a successful attack on one exchange rate leads to its real depreciation which enhances the competitiveness of the country's merchandise exports. This produces a trade deficit in the second country, a gradual decline in the international reserves of its central bank and ultimately an attack on its currency. A second channel for currency crisis transmission is the impact of crisis and depreciation in the first country on the import prices and the overall price level in the second. As highlighted in Eichengreen, et al. (1996), post-crisis real depreciation in the first country reduces import prices in the second. In turn, this reduction decreases its consumer price index and the demand for money by its residents. Their efforts to swap domestic currency for foreign exchange, then, deplete the foreign reserves of the central bank. This depletion may shift the second economy from a no-attack equilibrium in which reserves more than suffice to absorb the volume of prospective speculative sales and in which there consequently exist no

\footnotetext{
${ }^{3}$ In 2008, concerns about the viability of US Dollar brought the trade system to the brink of collapse.

${ }^{4}$ Haidar (2009b) establishes the link between investor protections and economic growth.

${ }^{5}$ For more details on the relationship between currency valuation and PPP, see Haidar (2011b).
}

grounds for a speculative attack, to a second equilibrium in which an attack can succeed. The authors empirically revealed that a currency crisis in one country exerts a contagion effect on countries with which it has strong trade links. Similarly, Glick and Rose (1999) revealed that currency crises tend to be regional, claiming that trade links are the main reason for this phenomenon. When a currency crisis occurs in one country, international investors carry out speculative attacks on the currency of other countries with strong trade relationships.

Buiter et al. (1996) use an escape-clause model of exchange rate policy to analyze the spread of currency crises in a system of $N+1$ countries, $N$ of which (denoted the "periphery") peg to the remaining country (the "center"). The center is more risk averse than the others and is hence unwilling to pursue a cooperative monetary policy designed to stabilize exchange rates. A negative shock to the center which leads it to raise interest rates then induces the members of the peripheries to reconsider their currency-peg policy. If the members of the periphery cooperate, they may find it collectively optimal to leave the system - an extreme case of contagion. More generally, some subset of peripheral countries - those with the least tolerance for high interest rates - will find it optimal to leave the system under these circumstances, and contagion will be limited to this subset. Importantly, however, their decision to leave stabilizes the currency pegs of the remaining members of the system, because monetary expansion and currency depreciation by some members of the periphery provides an incentive for the center country, which then finds itself with an increasingly overvalued exchange rate, to relax its monetary stance, relieving the pressure on rest of the periphery. In this model, contagion is selective: the shock to the center spills over negatively to some members of the periphery but positively to others.

Corsetti, et al. (1999) developed a model of financial and currency crises led by moral hazard. They showed that low foreign exchange reserves and high shares of non-performing loans were at the core of the 1997 Asian collapse. Their study assumes that the overvaluation of real exchange rates leads to the high possibility of a currency crisis. Such a currency crisis in a foreign country can cause the overvaluation of real exchange rates in the home country and so lead to the high possibility of a currency crisis being transmitted through both channels.

The above models do not incorporate explicit microeconomic foundations with dynamic and inter-temporal effects. Between 1999 and today, however, the "New Open Economy Macroeconomics" evolved considerably and moved towards dynamic stochastic general equilibrium models. Corsetti, et al. (2000) used the three-country model with a nested consumption basket to distinguish between goods produced in two periphery countries and a core country. Such a setup allowed tracing shifts in consumption (and thus the transmission of a shock like a currency crisis) depending on substitutability and complementarity of the traded goods. Their paper studied the mechanism of international transmission of exchange rate shocks within a 3-country Center-Periphery model, providing a choicetheoretic framework for the policy analysis and empirical assessment of competitive devaluations. Later, Forbes (2001) measured whether trade linkages are important determinants of a country's vulnerability to crises that originate elsewhere in the world. Subsequently, Ito and Hashimoto (2005) used daily data during the period of Asian currency crises to examine high-frequency contagion effects among six Asian countries. By identifying the origin (of exchange rate depreciation, or decline in stock prices) and the affected (currencies, or stock prices) in spillover relationship, Indonesia and Korea were found to be the two main origin countries, affecting exchange rates and stock prices of other countries. Evidence of high-frequency crisis spillover from Thailand to other countries was weak at best. The authors found a positive relationship between trade link indices and the contagion coefficients, implying that the bilateral trade linkage is an 
important factor for currency market participants to expect which currency should be affected within days of an original a shock in the exchange rate of a particular country. In recent policy debates some have argued that expansionary monetary policy in Japan can increase real output in Japan and in Japan's neighbors, while others have warned that it is a beggar-thy-neighbor policy. Mackowiak (2006) estimated structural vector auto regressions to assess the effects of Japanese monetary policy shocks. He found that the effects of Japanese monetary policy shocks on macroeconomic variation in East Asia have been modest and difficult to reconcile with the beggar-thy-neighbor view. Existing studies have not taken into much consideration the real sector channel, so this study concentrates on the transmission of contagion effects through this medium.

The present paper contributes to the literature in three ways. First, it builds a new dynamic general equilibrium three-country model to study international macroeconomic linkages related to currency crises transmission. Second, it develops a new misalignment method to study impacts of currency crisis transmission. Third, theoretically, it establishes existence of an international trade channel capable of transmitting a currency crisis and, thus, causing a regional currency crises. When capital moves to a trade partner from a trade competitor, for instance, the terms of trade change and lead to a currency depreciation at home and foreign countries. In addition, a misalignment between actual real exchange rate and equilibrium real exchange rate occurs when the latter decreases, causing a potential currency devaluation. Thus, to re-establish equilibrium, nominal exchange rates in foreign and home countries adjust, transmitting a currency crisis to home country from a foreign country. Mainly, this study dissects the mechanism of currency crisis transmission through international trade and presents a reasoning for its regional nature.

This paper proceeds as follows. Section 2 develops a new threecountry model to present how currency crisis can transmit across countries via the trade channel. Section 3 shows the mechanism for calculating the prices of nontradables, exportables, and importables. Section 4 demonstrates the connection between terms of trade real exchange rates. Section 5 analyzes the effect of capital movement from a trade competitor to a trade partner in the model. Section 6 concludes.

\section{The model}

We consider a three-country general equilibrium model in an open economy world. There are three countries ( $\mathrm{H}, \mathrm{C}$ and $\mathrm{T}$ ) in the world. Country $\mathrm{H}$ is the home country, country $\mathrm{C}$ is a trade competitor, and country $\mathrm{T}$ is a trade partner. Fig. 1 illustrates the trade relationship between the 3 countries in our model. Country C competes with country $\mathrm{H}$ to export and import. Country $\mathrm{T}$ imports country H's and C's exportables and exports country H's and C's importables.
The countries produce and consume importables $(M)$, exportables $(X)$, and nontradables $\left(N^{H}, N^{C}, N^{T}\right)$. Nontradables and budget constraints are country-specific. The model also considers two periods and allows for foreign borrowing and lending. Small letters represent period 1 and capital letters represent period 2. Conditional on budget constraints and on techonology and factors of production, in each period, consumers and producers optimize utility and profits, respectively. So the consumer problem would be:

$\max \Omega\left\{u\left(c_{N}, c_{M}, c_{X}\right) ; U\left(C_{N}, C_{M}, C_{X}\right)\right\}$

where $c_{N}, c_{M}, c_{X}\left(C_{N}, C_{M}, C_{X}\right)$ represent consumptions of nontradables, importables, and exportables in period 1 (period 2 ), and $\Omega$ represents total welfare.

Revenue functions represent the outcome of this optimization process. Let $r$ be the revenue in period $1, R$ be the revenue in period $2, v$ be a vector of factors of production in period 1 , and $(V)$ be a vector of factors of production in period 2, $p$ be the price of importables in period $1, P$ be the price of importables in period $2, q$ be the price of nontradables in period 1 , and $Q$ be the price of nontradables in period 2. Then,

$r=r(1, p, q ; v) ; R=R(1, P, Q ; V)$.

Let expenditure function (E) represent demand, $\pi$ be the price index in period 1 , and $\Pi$ be the price index in period 2 :

$E=E\{\pi(1, p, q), \delta \Pi(1, P, Q): \Omega)$.

The simultaneous solutions of the consumers and producers optimization problems allow us to obtain equilibrium. In each time period, the nontradables markets in the three countries are clear. These relationships between the 3 countries satisfy the equilibrium of international trade, assuming these budget constraints:

$$
\begin{aligned}
& r^{H}\left(1, p, q^{H}: v^{H}\right)+\delta R^{H}\left(1, P, Q^{H} ; V^{H}\right) \\
& \quad=E^{H}\left\{\pi^{H}\left(1, p, q^{H}\right), \delta \Pi^{H}\left(1, P, Q^{H}\right): \Omega^{H}\right\} \\
& r^{C}\left(1, p, q^{C}: v^{C}\right)+\delta R^{C}\left(1, P, Q^{C} ; V^{C}\right) \\
& \quad=E^{C}\left\{\pi^{C}\left(1, p, q^{C}\right), \delta \Pi^{C}\left(1, P, Q^{C}\right): \Omega^{C}\right\} \\
& r^{T}\left(1, p, q^{T}: v^{T}\right)+\delta R^{T}\left(1, P, Q^{T} ; V^{T}\right) \\
& \quad=E^{T}\left\{\pi^{T}\left(1, p, q^{T}\right), \delta \Pi^{T}\left(1, P, Q^{T}\right): \Omega^{T}\right\}
\end{aligned}
$$

And, for both time periods in the three countries, the nontradables markets equilibrium conditions are:

$$
\begin{aligned}
& r_{q}^{H}=E_{q}^{H} \\
& R_{Q}^{H}=E_{Q}^{H} \\
& r_{q}^{C}=E_{q}^{C} \\
& R_{Q}^{C}=E_{Q}^{C} \\
& r_{q}^{T}=E_{q}^{T} \\
& R_{Q}^{T}=E_{Q}^{T} .
\end{aligned}
$$

Eqs. (7) and (8) show that the demand and supply of the domestic nontradables sectors match in periods 1 and 2. Eqs. (9)-(12) show the conditions for C and T's equilibria of nontradables sectors in both time periods. The model normalizes the price of exportables as

Fig. 1. Trade relationship in a three-country model. 
1. Thus, it does not express the quantity of exportables using partial derivatives of demand or revenue functions. Below Eqs. (13)-(16) describe the exportables and importables world markets. And, $s$ and $d(S$ and $D$ ) represent the exportables supply and demand in period 1 (pe$\operatorname{riod} 2$ ).

$s^{H}+s^{C}+s^{T}=d^{H}+d^{C}+d^{T}$

$S^{H}+S^{C}+S^{T}=D^{H}+D^{C}+D^{T}$

$r_{p}^{H}+r_{p}^{C}+r_{p}^{T}=E_{p}^{H}+E_{p}^{C}+E_{p}^{T}$

$R_{P}^{H}+R_{P}^{C}+R_{P}^{T}=E_{P}^{H}+E_{P}^{C}+E_{P}^{T}$

Eqs. (13)-(14) indicate that the exportables world demand and supply match in each time period, and Eqs. (15)-(16) indicate that the importables world demand and supply match in each time period.

\section{Price setting}

We use charts to explain capital movement effects in a threecountry model to reduce complexity of mathematical analysis. The charts show the equilibrium of period 2. They present the $N^{T} N^{T}$ curve for country $T, N^{C} N^{C}$ curve for country $C, N^{H} N^{H}$ curve for country $H$, as well as $M^{S} M^{S}$ and $M^{D} M^{D}$ curves for the three countries. The $N^{H} N^{H}$ curve shows the relationship between the price of nontradables in country $H, Q^{H}$, and the price of importables in period $2, P$, in condition that the budget constraint of country $H$ is satisfied, and the nontradables markets of the country $H$ in each time period clear. The $N^{T} N^{T}$ and $N^{C} N^{C}$ curves for country $T$ equal the $N^{T} N^{T}$ and $N^{C} N^{C}$ curves for country $C$. In condition that, in each time period for the three countries, the budget constraints are satisfied and the nontradables markets are clear, (i) the $M^{S} M^{S}$ curve shows the relationship between the relative supply of importables to exportables in period $2, R_{P} / S$, and the price of importables in period 2, $P$; and (ii) the $M^{D} M^{D}$ curve describes the relationship between the relative demand of importables to exportables in period $2, E_{P} / D$, and the price of importables in period 2, $P$. These curves allow establishing the prices of nontradables and importables in the three countries as well as the equilibrium quantities of nontradables, exportables, and importables in period 2.

The $N^{H} N^{H}$ curve sketches how an external term of trade shock affects the equilibrium real exchange rates. These effects can be expressed for the home country, using Eqs. (4), (7), and (8), as follows:

$$
\begin{aligned}
& d Q^{H} / d p=- 1 / \triangle_{1}\left\{\left(E_{P Q}^{H}-R_{P Q}^{H}\right)\left(r_{q q}^{H}-E_{q q}^{H}\right)+E_{q p}^{H} E_{Q q}^{H}\right\} \\
&+ 1 / \triangle_{1}\left\{\left(E_{P}^{H}-R_{P}^{H}\right)\left(E_{Q q}^{H} \pi_{q}^{H} E_{\pi \Omega}^{H}+\Pi_{Q}^{H} E_{\Pi \Omega}^{H}\left(r_{q q}^{H}-E_{q q}^{H}\right)\right\}\right. \\
& \triangle_{1}\left\{\left(R_{Q Q}^{H}-E_{Q Q}^{H}\right)\left(r_{q q}^{H}-E_{q q}^{H}\right)+E_{q Q}^{H} E_{Q q}^{H}\right\}<0
\end{aligned}
$$

where the terms $E_{\pi \Omega}$ and $E_{\Pi \Omega}$, which capture the income effects in each time period, are positive, and $\Delta_{1}$ is negative. The temporary terms of trade shock will affect equilibrium real exchange rates but the direction of the effect is unknown because income has a negative effect (Eq. (17)). $\frac{d Q}{d P}$ can be negative if the income effect dominates substitution effect.

Then, we look at the intertemporal substitution effect. The demand of nontradables would increase if the price of importables goes up, causing an increase in the price of nontradables in period 1 as well as in the demand and price of nontradables in period 2 to recover the nontradables market equilibrium, as shown in the first term of Eq. (17). a) The $\mathrm{N}^{\mathrm{H}} \mathrm{N}^{\mathrm{H}}$ Curve

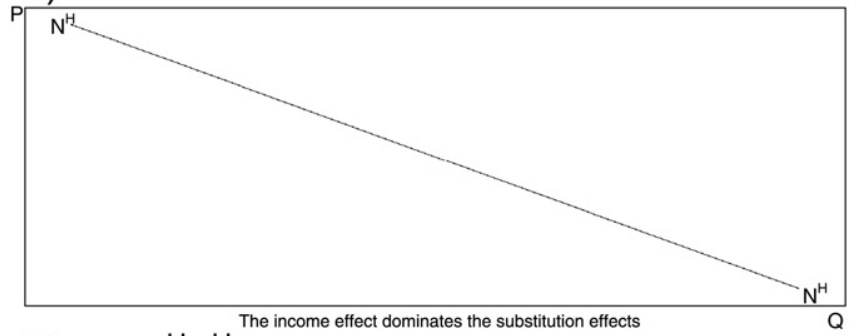

b) The $\mathrm{N}^{\mathrm{H}} \mathrm{N}^{\mathrm{H}}$ Curve

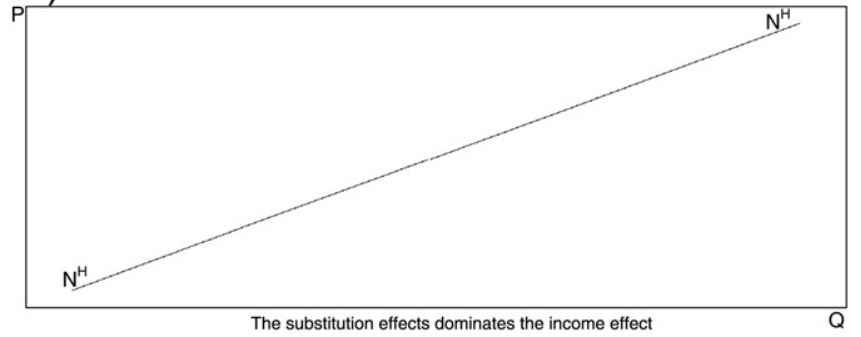

Fig. 2. a. The $\mathrm{N}^{\mathrm{H}} \mathrm{N}^{\mathrm{H}}$ curve. The income effect dominates the substitution effects. b. The $\mathrm{N}^{\mathrm{H}} \mathrm{N}^{\mathrm{H}}$ curve. The substitution effect dominates the income effect.

The corresponding relationships for countries $C$ and $T$ are:

$$
\begin{gathered}
d Q^{C} / d p=-1 / \triangle_{2}\left\{\left(E_{P Q}^{C}-R_{P Q}^{C}\right)\left(r_{q q}^{C}-E_{q q}^{C}\right)+E_{q p}^{C} E_{Q q}^{C}\right\} \\
+1 / \triangle_{2}\left\{\left(E_{P}^{C}-R_{P}^{C}\right)\left(E_{Q q}^{C} \pi_{q}^{C} E_{\pi \Omega}^{C}+\Pi_{Q}^{C} E_{\Pi \Omega}^{C}\left(r_{q q}^{C}-E_{q q}^{C}\right)\right\}\right. \\
\triangle_{2}\left\{\left(R_{Q Q}^{C}-E_{Q Q}^{C}\right)\left(r_{q q}^{C}-E_{q q}^{C}\right)+E_{q Q}^{C} E_{Q q}^{C}\right\}<0 \\
d Q^{T} / d p=-1 / \triangle_{3}\left\{\left(E_{P Q}^{T}-R_{P Q}^{T}\right)\left(r_{q q}^{T}-E_{q q}^{T}\right)+E_{q p}^{T} E_{Q q}^{T}\right\} \\
+1 / \triangle_{3}\left\{\left(E_{P}^{T}-R_{P}^{T}\right)\left(E_{Q q}^{T} \pi_{q}^{T} E_{\pi \Omega}^{T}+\Pi_{Q}^{T} E_{\Pi \Omega}^{T}\left(r_{q q}^{T}-E_{q q}^{T}\right)\right\}\right. \\
\triangle_{3}\left\{\left(R_{Q Q}^{T}-E_{Q Q}^{T}\right)\left(r_{q q}^{T}-E_{q q}^{T}\right)+E_{q Q}^{T} E_{Q q}^{T}\right\}<0
\end{gathered}
$$

Fig. 2a illustrates the $N^{H} N^{H}$ curve when the income effect dominates the intertemporal and intratemporal substitution effects.

Fig. 2b illustrates the $N^{H} N^{H}$ curve when the intertemporal and intratemporal substitution effects dominate the income effect.

Eq. (17) expresses the schedule in the two figures for country $H$. Figs. 2a and $2 \mathrm{~b}$ apply to countries $\mathrm{C}$ and $\mathrm{T}$ as well.

The sum of world demand and supply determines the exportables and importables world markets equilibria. This section addresses the supply of exportables and importables. ${ }^{6}$

$R_{P}^{H}+R_{P}^{C}+R_{P}^{T}=R_{P}^{W}$

$S^{H}+S^{C}+S^{T}=S^{W}$

Each of the world supply of importables in period $2\left(R_{P}^{W}\right)$ and the world supply of exportables in period $2\left(S^{W}\right)$ equals the sum of the relevant supply from countries $H, C$, and $T$ (Eqs. (20), (21)). The $M^{S} M^{S}$ schedule, which is sketched in Fig. 3 and that satisfies Eqs. (4)-(12), (20), and (21), shows the relationship between the price of importables and the relative world supply of importables to exportables in period 2 subject to that the nontradable sectors and the budget constraints in each time period are clear. We assume that (i) the substitution effects in importables and exportables production with respect to $q^{H}, q^{C}, q^{T}, Q^{H}, Q^{C}, Q^{T}$ and $p$ are similar and (ii) the supply of importables and exportables is similar

\footnotetext{
${ }^{6}$ The partial derivative of the supply of exportables is as follow: $S_{P}<0, S_{Q}<0$
} 


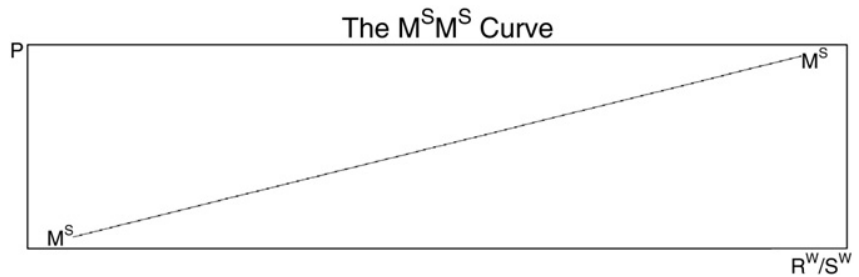

Fig. 3. The $M^{S} M^{S}$ curve.

at the initial equilibrium point. Therefore, the total derivatives of Eqs. (4)-(12), (20), and (21) allow us to deduce the slope of the $M^{S} M^{S}$ schedule.

Then,

$$
\begin{aligned}
d\left(R_{P}^{W} / S^{W}\right) / d P= & \left(1 / S^{W}\right)\left[\left(\triangle_{4}+\triangle_{5}\right)+\left(R_{P Q}^{H}-S_{Q}^{H}\right) \triangle_{8}+\left(R_{P Q}^{C}-S_{Q}^{C}\right) \triangle_{9}\right. \\
& +\left(R_{P Q}^{T}-S_{Q}^{T}\right) \triangle_{10}+\left(R_{P p}^{H}-S_{p}^{H}\right) \triangle_{11}+\left(R_{P p}^{C}-S_{p}^{C}\right) \triangle_{12} \\
& +\left(R_{P p}^{T}-S_{p}^{T}\right) \triangle_{13}+\left(R_{P q}^{H}-S_{q}^{H}\right) \triangle_{14}+\left(R_{P q}^{C}-S_{q}^{C}\right) \triangle_{15} \\
& \left.+\left(R_{P q}^{T}-S_{q}^{T}\right) \triangle_{16}\right] \\
& \Delta_{8}=\left(\left(E_{Q P}^{H}-R_{Q P}^{H}\right)-\left(E_{P}^{H}-R_{P}^{H}\right) /\left(E_{Q \Omega}^{H} / E_{\Omega}^{H}\right)\right) /\left(R_{Q Q}^{H}-E_{Q Q}^{H}\right) \\
& \Delta_{9}=\left(\left(E_{Q P}^{C}-R_{Q P}^{C}\right)-\left(E_{P}^{C}-R_{P}^{C}\right) /\left(E_{Q \Omega}^{C} / E_{\Omega}^{C}\right)\right) /\left(R_{Q Q}^{C}-E_{Q Q}^{C}\right) \\
& \Delta_{10}=\left(\left(E_{Q P}^{T}-R_{Q P}^{T}\right)-\left(E_{P}^{T}-R_{P}^{T}\right) /\left(E_{Q \Omega}^{T} / E_{\Omega}^{T}\right)\right) /\left(R_{Q Q}^{T}-E_{Q Q}^{T}\right) \\
& \Delta_{11}=\left(\left(E_{p P}^{H}-r_{p P}^{H}\right)-\left(E_{p}^{H}-r_{p}^{H}\right) /\left(E_{q \Omega}^{H} / E_{\Omega}^{H}\right)\right) /\left(r_{q q}^{H}-E_{q q}^{H}\right) \\
& \Delta_{12}=\left(\left(E_{p P}^{C}-r_{p P}^{C}\right)-\left(E_{p}^{C}-r_{p}^{C}\right) /\left(E_{q \Omega}^{C} / E_{\Omega}^{C}\right)\right) /\left(r_{q q}^{C}-E_{q q}^{C}\right) \\
& \Delta_{13}=\left(\left(E_{p P}^{T}-r_{p P}^{T}\right)-\left(E_{p}^{T}-r_{p}^{T}\right) /\left(E_{q \Omega}^{T} / E_{\Omega}^{T}\right)\right) /\left(r_{q q}^{T}-E_{q q}^{T}\right) \\
& \Delta_{14}=\left(\left(E_{q P}^{H}-r_{q P}^{H}\right)-\left(E_{q}^{H}-r_{q}^{H}\right) /\left(E_{q \Omega}^{H} / E_{\Omega}^{H}\right)\right) /\left(r_{q q}^{H}-E_{q q}^{H}\right) \\
& \Delta_{15}=\left(\left(E_{q P}^{C}-r_{q P}^{C}\right)-\left(E_{q}^{C}-r_{q}^{C}\right) /\left(E_{q \Omega}^{C} / E_{\Omega}^{C}\right)\right) /\left(r_{q q}^{C}-E_{q q}^{C}\right) \\
& \Delta_{16}=\left(\left(E_{q P}^{T}-r_{q P}^{T}\right)-\left(E_{q}^{T}-r_{q}^{T}\right) /\left(E_{q \Omega}^{T} / E_{\Omega}^{T}\right)\right) /\left(r_{q q}^{T}-E_{q q}^{T}\right) .
\end{aligned}
$$

Given we assume that the substitution effects on exportables production with respect to $q, Q$ and $p$ are the same as for those on importables production, then the slope of $M^{S} M^{S}$ would be positive.

$d\left(R_{P}^{W} / S^{W}\right) / d P=\triangle_{4}+\triangle_{5}$

$\Delta_{4}=R_{P P}^{H}+R_{P P}^{C}+R_{P P}^{T}$

$\Delta_{5}=-S_{P}^{H}-S_{P}^{C}-S_{P}^{T}$

In other words, the relative supply of importables to exportables would be positively associated with the price of importables in period 2 in condition that the market clearing conditions of the nontradables sectors and budget constraints in each time period are clear. Fig. 3 illustrates these results.

Now, we consider the demand for exportables and importables in period $2^{7}$ :

$E_{P}^{H}+E_{P}^{C}+E_{P}^{T}=E_{P}^{W}$

$D^{H}+D^{C}+D^{T}=D^{W}$

Eqs. (23) and (24) describe the demand of countries $H, C$, and $T$ in period 2 for importables and exportables, respectively. The $M^{D} M^{D}$ schedule, which is sketched in Fig. 4 and that satisfies Eqs. (4)-(12), (23), and (24), shows the relationship between the price of

\footnotetext{
${ }^{7}$ The partial derivative of the demand of exportables is as follow; $D_{P}>0, D_{Q}>0$.
}

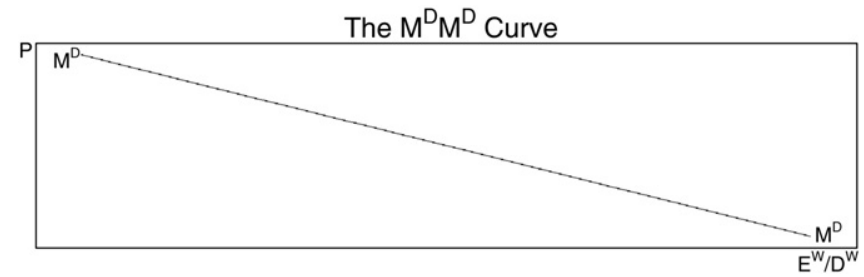

Fig. 4. The $\mathrm{M}^{\mathrm{D}} \mathrm{M}^{\mathrm{D}}$ curve.

importables and the relative demand of importables over exportables in period 2 subject to that the nontradable sectors and the budget constraints in each time period are clear.

We assume that (i) the substitution effects in importables and exportables production with respect to $q^{H}, q^{C}, q^{T}, Q^{H}, Q^{C}, Q^{T}$ and $p$ are similar and (ii) the demand of importables and exportables is similar at the initial equilibrium point.

$$
\begin{aligned}
d\left(E_{P}^{W} / D^{W}\right) / d P= & \left(1 / D^{W}\right)\left[\left(\triangle_{6}+\triangle_{7}\right)+\left(E_{P Q}^{H}-D_{Q}^{H}\right) \triangle_{8}+\left(E_{P Q}^{C}-D_{Q}^{C}\right) \triangle_{9}\right. \\
& +\left(E_{P Q}^{T}-D_{Q}^{T}\right) \triangle_{10}+\left(E_{P p}^{H}-D_{p}^{H}\right) \triangle_{11}+\left(E_{P p}^{C}-D_{p}^{C}\right) \triangle_{12} \\
& +\left(E_{P p}^{T}-D_{p}^{T}\right) \triangle_{13}+\left(E_{P q}^{H}-D_{q}^{H}\right) \triangle_{14}+\left(E_{P q}^{C}-D_{q}^{C}\right) \triangle_{15} \\
& \left.+\left(E_{P q}^{T}-D_{q}^{T}\right) \triangle_{16}\right] \\
& \Delta_{8}=\left(\left(E_{Q P}^{H}-R_{Q P}^{H}\right)-\left(E_{P}^{H}-R_{P}^{H}\right) /\left(E_{Q \Omega}^{H} / E_{\Omega}^{H}\right)\right) /\left(R_{Q Q}^{H}-E_{Q Q}^{H}\right) \\
& \Delta_{9}=\left(\left(E_{Q P}^{C}-R_{Q P}^{C}\right)-\left(E_{P}^{C}-R_{P}^{C}\right) /\left(E_{Q \Omega}^{C} / E_{\Omega}^{C}\right)\right) /\left(R_{Q Q}^{C}-E_{Q Q}^{C}\right) \\
& \Delta_{10}=\left(\left(E_{Q P}^{T}-R_{Q P}^{T}\right)-\left(E_{P}^{T}-R_{P}^{T}\right) /\left(E_{Q \Omega}^{T} / E_{\Omega}^{T}\right)\right) /\left(R_{Q Q}^{T}-E_{Q Q}^{T}\right) \\
& \Delta_{11}=\left(\left(E_{p P}^{H}-r_{p P}^{H}\right)-\left(E_{p}^{H}-r_{p}^{H}\right) /\left(E_{q \Omega}^{H} / E_{\Omega}^{H}\right)\right) /\left(r_{q q}^{H}-E_{q q}^{H}\right) \\
& \Delta_{12}=\left(\left(E_{p P}^{C}-r_{p P}^{C}\right)-\left(E_{p}^{C}-r_{p}^{C}\right) /\left(E_{q \Omega}^{C} / E_{\Omega}^{C}\right)\right) /\left(r_{q q}^{C}-E_{q q}^{C}\right) \\
& \Delta_{13}=\left(\left(E_{p P}^{T}-r_{p P}^{T}\right)-\left(E_{p}^{T}-r_{p}^{T}\right) /\left(E_{q \Omega}^{T} / E_{\Omega}^{T}\right)\right) /\left(r_{q q}^{T}-E_{q q}^{T}\right) \\
& \Delta_{14}=\left(\left(E_{q P}^{H}-r_{q P}^{H}\right)-\left(E_{q}^{H}-r_{q}^{H}\right) /\left(E_{q \Omega}^{H} / E_{\Omega}^{H}\right)\right) /\left(r_{q q}^{H}-E_{q q}^{H}\right) \\
& \Delta_{15}=\left(\left(E_{q P}^{C}-r_{q P}^{C}\right)-\left(E_{q}^{C}-r_{q}^{C}\right) /\left(E_{q \Omega}^{C} / E_{\Omega}^{C}\right)\right) /\left(r_{q q}^{C}-E_{q q}^{C}\right) \\
& \Delta_{16}=\left(\left(E_{q P}^{T}-r_{q P}^{T}\right)-\left(E_{q}^{T}-r_{q}^{T}\right) /\left(E_{q \Omega}^{T} / E_{\Omega}^{T}\right)\right) /\left(r_{q q}^{T}-E_{q q}^{T}\right)
\end{aligned}
$$

Then, the slope of $M^{D} M^{D}$ would be negative, leading to:

$$
\begin{aligned}
& \left(E_{P}^{W} / D^{W}\right) / d P=\triangle_{6}+\triangle_{7} \\
& \Delta_{6}=E_{P P}^{H}+E_{P P}^{C}+E_{P P}^{T} \\
& \Delta_{7}=-D_{P}^{H}-D_{P}^{C}-D_{P}^{T} .
\end{aligned}
$$

\section{Real exchange rates and terms of trade}

Fig. 5 demonstrates graphically how terms of trade allow us to determine the real exchange rates of countries $H, C$, and $T$ in period 2 . The initial equilibrium point is at $A$, which also shows the world price of importables, $P$, and the relative amount of importables to exportables, $M / X$. Point $A$ allows abstracting the domestic and foreign prices of nontradables in period 2 . These prices correspond to the relevant points along the $N^{H} N^{H}, N^{C} N^{C}$, and $N^{T} N^{T}$ schedules, and they allow calculating the exportables-based real exchange rates of each country, $1 / Q^{H}, 1 / Q^{C}$, and $1 / Q^{T}$. In each country, the price of nontradables, $Q$ which is determined by the equilibrium points, $A, a$, and $b$, decides each country's supply of nontradables. Fig. 5 expresses the general equilibrium of the model, and it allows determining the equilibrium value of the terms of trade and amount of importables, exportables, and nontradables. Furthermore, $a^{H}$ is the price of 


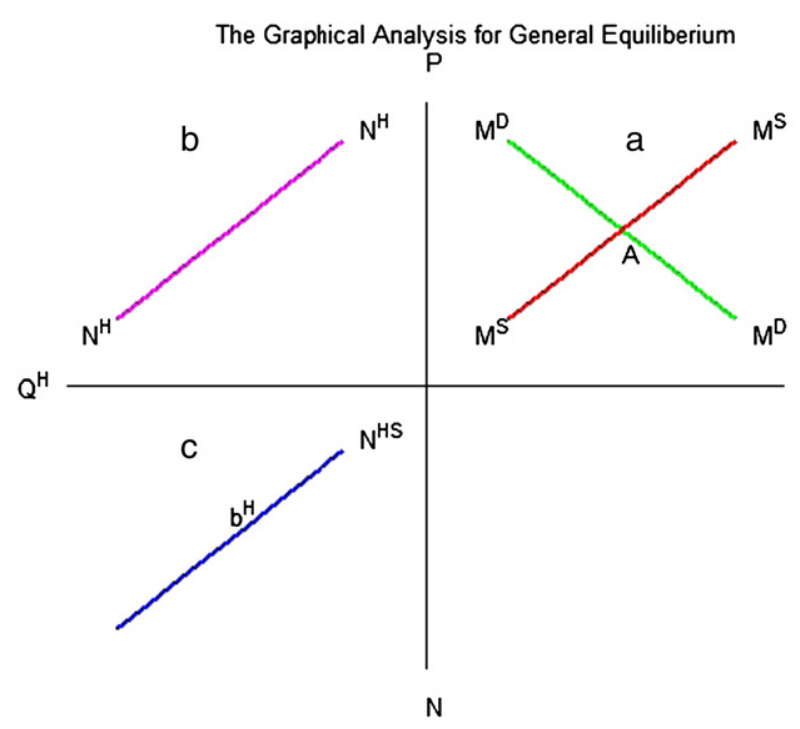

Fig. 5. The graphical analysis for the general equilibrium.

nontradables of home country along the $N^{H} N^{H}$, and $b^{H}$ is the value of domestic nontradables supply.

\section{Capital movement}

Suppose that there are exogenous capital movements from a trade partner to a trade competitor in period 1 and from a trade competitor to a trade partner in period 2 . The trade competitor borrows capital from the trade partner in period 1 and pays back in period 2:

$$
\begin{aligned}
& r^{C}\left(1, p, q^{C} ; v^{C}\right)+\delta R^{C}\left(1, P, Q^{C} ; V^{C}\right)+C M 1-\delta C M 2 \\
& \quad=E^{C}\left\{\pi^{C}\left(1, p, q^{C}\right), \delta \Pi^{C}\left(1, P, Q^{C}\right): \Omega^{C}\right\} \\
& r^{T}\left(1, p, q^{T} ; v^{T}\right)+\delta R^{T}\left(1, P, Q^{T} ; V^{T}\right)+C M 1-\delta C M 2 \\
& \quad=E^{T}\left\{\pi^{T}\left(1, p, q^{T}\right), \delta \Pi^{T}\left(1, P, Q^{T}\right): \Omega^{T}\right\}
\end{aligned}
$$

where CM1 is the capital movement from trade partner to trade competitor in period 1, CM2 is the capital movement from trade competitor to trade partner in period 2, and $r$ is the exogenous real interest rate. Given foreign borrowing and lending are allowed in our three-country model setting, we would need to analyze the effects of exogenous capital movements between the trade partner and trade competitor in period 2 to be able to look at currency crises from an unexpected capital outflows perspective. Then, we would be able to analyze the effects of currency crises from a speculative attacks perspective.

A look at the movement of the $N^{C} N^{C}$ curve due to capital outflow from country $C$ in time period 2 reveals that such capital outflow would result in a shrink in country $C^{\prime} s$ budget and nontradables consumption, causing the price of nontradables, $Q^{C}$, to decline in order to recover equilibrium (Eq. (29)). The $N^{C} N^{C}$ curve has a downward slope as the value of its partial derivative is negative.

$-d Q^{C} / d C M 2=-\left(E_{Q \Omega}^{C} / E_{\Omega}^{C}\right) /\left(R_{Q Q}^{C}-E_{Q Q}^{C}\right) \leq 0$

The $M^{D} M^{D}$ curve shifts as well due to the capital movement. Let the substitution effects on the consumption of importables and exportables with respect to $q^{H}, q^{C}, q^{T}, Q^{H}, Q^{C}, Q^{T}$ and $p$ be equal. Then, the $M^{D} M^{D}$ curve moves according to the demand elasticity of importables and exportables consumption with respect to the income of each of the trade competitor and partner, following:

$$
\begin{aligned}
& d\left(E_{P} / D\right) / d C 12=\left(E_{P \Omega}^{T}-E_{P \Omega}^{C}+D_{\Omega}^{C}-D_{\Omega}^{T}\right)+\triangle_{17}\left(E_{P Q}^{T}-D_{Q}^{T}\right)-\triangle_{18}\left(E_{P Q}^{C}-D_{Q}^{C}\right) \\
& \triangle_{17}=\left(E_{Q C \Omega}^{T} / E_{\Omega}^{T}\right) /\left(R_{Q Q}^{T}-E_{Q Q}^{T}\right) \\
& \triangle_{18}=\left(E_{Q \Omega}^{C} / E_{\Omega}^{C}\right) /\left(R_{Q Q}^{C}-E_{Q Q}^{C}\right) .
\end{aligned}
$$

If the substitution effects of consumption of importables and exportables with respect to a nontradables price increase are the same, then the movement direction of the $M^{D} M^{D}$ curve would be:

$d\left(E_{P}^{W} / D^{W}\right) / d C M 2=\left(E_{P \Omega}^{T}-E_{P \Omega}^{C}+D_{\Omega}^{C}-D_{\Omega}^{T}\right) \geq 0$ or $\leq 0$.

However, if the substitution effects on the supply of importables and exportables with respect to nontradables prices are equal, then the capital movement from trade competitor to trade partner would not shift the $M^{S} M^{S}$ curve:

$d\left(R_{P}^{W} / S^{W}\right) / d C M 2=0$

Fig. 6 shows that the $M^{S} M^{S}$ curve does not shift while the $M^{D} M^{D}$ curve shifts upward, increasing the price of importables, $P$. This relationship indicates a terms of trade deterioration in countries $H$ and $C$ but an improvement in country $T$. The $N^{C} N^{C}$ curve moves downwards because of the direct effect of capital outflow from country $C$. The terms of trade deterioration gives rise to three kinds of indirect effects: negative income, intratemporal substitution, and intertemporal substitution effects. The negative income effect decpreciates currencies in countries $H$ and $C$. The intratemporal and intertemporal substitution effects, however, appreciate currencies in countries $H$ and $C$. The relative magnitude and significance of these three effects determine the total impact. This paper focuses on analyzing the case where the income effect dominates the substitution effect.

\section{Conclusion}

Using a new three-country model, this paper shows the mechanism of a currency crisis transmission through international trade. Unlike earlier studies that use financial integration to model currency crisis transmission, we consider the international trade perspective.

Currency crises transmission is a recurring empirical phenomenon with substantial and potentially long lasting effects on (groups of

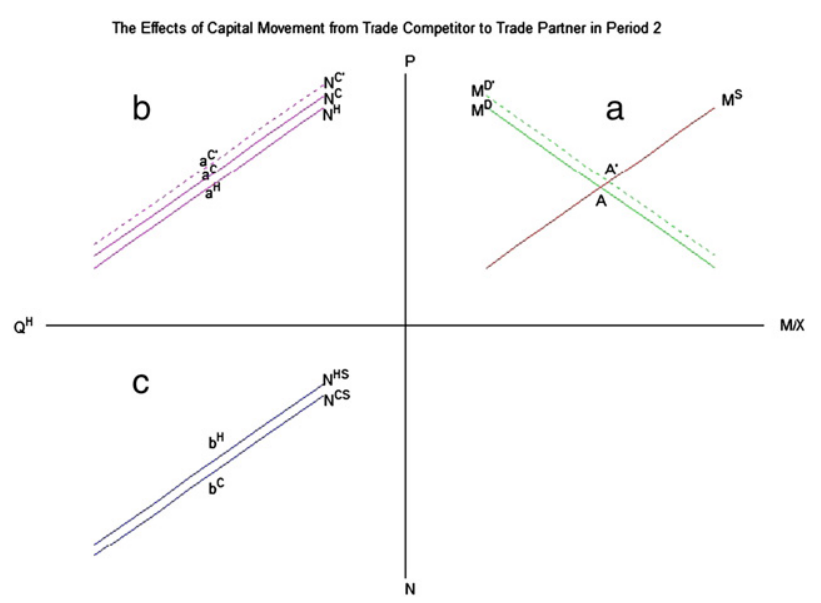

Fig. 6. The effects of capital movement from the trade competitor to trade partner in period 2. 
countries in) the world economy. This paper presents a theory for analyzing whether inter-country trade can be responsible for the transmission of a currency crisis, which has important implications for understanding the empirical phenomenon in general and possibly also its regional dimensions. Specifically, we try to (i) show how a currency crisis can transmit through the real (trade) sector channel; (ii) present how changes in a foreign country's capital flow condition can influence home country's exchange rate through the change in terms of trade; (iii) mathematically prove that the significance of the real sector channel between two countries is positively associated with their trade levels; (iv) offer a new trade-related explanation for the occurrence of currency crises between countries; and (v) describe how capital movement between two countries can lead to a currency crisis in one of these countries and in a third country.

This paper does not fully address the regional nature of currency crisis. It is true that many neighboring countries trade more with each other, and as such the terms of trade effect may be more pronounced between these countries. However, many countries have large trade relationships with the EU, the US, and also increasingly China. For instance, a currency crisis occurring in the US would affect many countries via contagion, as they have strong trade relationships with the US. The analysis in this paper focuses specifically on the question whether inter-country trade can be a channel that transmits currency crises. Further research can explore whether the financial sector channel alone is enough to transmit the currency crisis.

\section{References}

Buiter, Willem, Corsetti, Giancarlo, Pesenti, Paolo, 1996. Financial Markets and International Monetary Cooperation. Cambridge University Press, Cambridge.

Claessens, Stijn, 1991. Balance of payments crises in an optimal portfolio model. European Economic Review 35, 81-101.
Corsetti, Giancarlo, Pesenti, Paolo, Roubini, Nouriel, 1999. What caused the Asian currency and financial crisis? Japan and the World Economy, vol. 11(3). Elsevier, pp. 305-373.

Corsetti, Giancarlo, Pesenti, Paolo, Roubini, Nouriel, Tille, Cedric, 2000. Competitive devaluations: toward a welfare-based approach. Journal of International Economics 51 (1), 217-241.

Eichengreen, Barry, Rose, Andrew K., Wyplosz, Charles, 1996. Contagious currency crises. The Scandinavian Journal of Economics 98 (4), 463-484.

Flood, Robert, Garber, Peter, 1984. Collapsing exchange rate regimes: some linear examples. Journal of International Economics 17, 1-13.

Forbes, Kristin J., 2001. Are Trade Linkages Important Determinants of Country Vulnerability to Crises? NBER Working Papers 8194, National Bureau of Economic Research.

Gerlach, Stefan, Frank, Smets, 1995. Contagious speculative attacks. European Journal of Political Economy 11, 5-63.

Glick, Reuven, Rose, Andrew K., 1999. Contagion and trade: why are currency crises regional? Journal of International Money and Finance 18 (4), 603-617.

Goldberg, Linda, 1994. Predicting exchange rate crises: Mexico revisited. Journal of International Economics 36, 413-430.

Haidar, Jamal Ibrahim, 2011a. Sovereign Credit Risk in the Euro Zone. World Economics 13 (1).

Haidar, Jamal Ibrahim, 2011b. Currency Valuation and Purchasing Power Parity. World Economics 12 (3).

Haidar, 2011a. Sovereign Credit Risk in the Euro Zone. World Economics 12 (December 2011).

Haidar, Jamal Ibrahim, 2011b. Currency Valuation and Purchasing Power Parity. World Economics 12

Ito, Takatoshi, Hashimoto, Yuko, 2005. High-frequency contagion of currency crises in Asia. Asian Economic Journal 19 (4), 357-381.

Mackowiak, Bartosz, 2006. What does the Bank of Japan do to East Asia? Journal of International Economics 70 (1), 253-270.

Neary, Peter, 1988. Determinants of the equilibrium real exchange rate. American Economic Review 78 (1), 210-215.

Obstfeld, Maurice, 1986. Rational and self-fulfilling balance of payments crises. American Economic Review 76, 72-81.

Willman, Alpo, 1988. The collapse of the fixed exchange rate regime with sticky wages and imperfect substitutability between domestic and foreign bonds. European Economic Review 32, 1817-1838. 